\title{
Sissevaade eestlaste ravimtaimede tundmise mitmekesisusse
}

\begin{abstract}
Raivo Kalle, Renata Sõukand
Teesid: Artiklis uurime eestlaste ravimtaimede tundmist teadmiste päritolu seisukohalt. Oleme jaganud teadmised lokaalseteks ja globaalseteks. Lokaalsuse mõiste on seotud tihedalt pärismaiste taimedega ja nende tundmisega kogukonnas. Lokaalsele teabele on omane kaks omavahel kombineeruvat kriteeriumit: esiteks piirkonnale (küla, endisaegne kihelkond vms) iseloomulik taimenimetus või nimetuse puudusel äratuntav taimekirjeldus; teiseks piirkonnale omane kordumatu taimekasutus. Globaalne taimepärimus on seotud võõr- ja kultuurliikidega ning seda saab teabes eristada võõrtaimele omase nimetuse ja kasutuse alusel; võõrtaime nimetuse ja kasutusviiside ülekandumisega kohalikule liigile jne. Enamasti puudub võõrliikidel pärimuslik nimetus ja neid tuntakse üksnes botaanikute pandud nimetuste järgi. Esimesteks suuremateks äratuntavateks taimepärimuse mõjutajateks olid apteegid, kus müüdavate droogide nimed kattusid liikide nimedega. Põhjalikumalt on analüüsitud kibuvitsajuurte droogi nimetuse levimist pärimuses. Taimeteadmise mitmekesisust mõjutab ka eestikeelne aimekirjandus, mida on välja antud juba ligi 240 aastat, tänapäeval ka meedia ja seal esinevad autoriteedid. Viimastel aastakümnetel on Eestis paljud varem tavalised liigid muutunud haruldasteks, sama tendents on täheldatav ka taimravi pärimuses.
\end{abstract}

Märksõnad: Eesti taimepärimus, etnobotaanika, lokaalne ja globaalne, ravimtaimed, taimede nimetamine, teadmiste edasiandmine

Autorid viisid oma tutvusringkonnas (1970.-80. aastatel sündinud inimeste seas) läbi eksperimendi: inimestele näidati tänapäeval Eestis põllukultuurina tähtsusetut, kuid invasiivseks muutunud ja vähesel määral haljastuses leiduvat hulgalehise lupiini (Lupinus polyphyllus) taime ilma õiekobarata, ja küsiti, kas nad tunnevad seda taime. "Ei," vastasid kõik üheksa küsitletut. Kui neil paluti aga taime täpsemalt kirjeldada, oskasid kõik teha seda üsna äratuntavalt: kirjeldasid õite värvi, õisiku kuju ja seostasid tema kasvukohta inimese lähedusega. See viib mõttele, et tänapäeval mõeldakse taime tundmise all peamiselt nime teadmist. 
Eesti mandriosa vabanes mandrijääst umbes 11000 aastat $\mathrm{eKr}$ ja esimesed inimtegevuse jäljed on dateeritud 9000-5000 aastat eKr (Kriiska 2004: 15-18), järelikult oleme meie, eestlased, elanud siin paikselt tuhandeid aastaid, kohandanud selle aja jooksul loodust vastavalt oma vajadustele ja ennast vastavalt kohalikele oludele. Eestimaa oli ja on suhteliselt hõreda inimasustusega, sellepärast vahelduvad meie kultuurmaastikul looduslikud ja poollooduslikud kooslused. Hõre inimasustus, geograafiline asend, kliimaolud ja aluspinna lähtekivimid lõid eelduse suhteliselt liigirikka taimestiku tekkeks nii kogu territooriumil kui ka ruutmeetrisel seirealal (Kukk \& Kull 1997).

Rikkaliku taimestiku tõttu arvatakse et muistsed (ka ealt vanemad) inimesed tundsid/tunnevad taimi paremini kui arvajad ise:

\section{Taimede tarvitamine vanemal ajal}

Vanal ajal tundsid eestlased väga palju taimi ja mõistsid neid ka väga palju tarvitada. Näiteks, kui kellelgi köha oli, siis anti talle pärnaõieteed, reinvarre õie teed, nõmmekõrva teed, raudrohu teed või ka maasikaõie teed. Teine kord juhtus kellelgi jälle kõhuvalu olema, siis anti talle vaarikavarreteed või ka marana juuri viina sees leotatud. Või oli keegi liiga verevaene siis anti talle raudrohu teed või maasikaid. Õige tihti olid inimestel viletsad juuksed, siis pesti takja juurte veega, mis ummuses olid keedetud. Kui kellelgi paise oli siis pandi kartuli kaabet sinna pääle. Muidugi olid inimesed vahel sügelises, siis viheldi neid nõgestest vihaga. (Vilbaste, TN 7, 488 < Jõhvi khk, Kohtla-Järve - Kohtla-Järve algkooli juhataja August Eero < L. Kütt, Kohtla-Järve algkooli V klassi ópilane < vanemad, Friido Kütt, 54 a. ja Rosaalie Kütt, 42 a. (1929).)

Historistlikusse Eesti Rahvameditsiini Botaanilisse Andmebaasi (HERBA) (Sõukand \& Kalle 2008) koondatud tekstide esialgse analüüsi põhjal võib öelda, et osaliselt põhineb uskumus tõel, sest viimase sajandi jooksul on pärimuses kajastatud ravimtaimede valik veidi ahenenud ja kohalike liikide kasutus märkimisväärselt kahanenud. Pärismaiste liikide vähenemine toimus taimede rahvapäraste nimetuste ühtlustumise järel alates 1920 . aastatest. ${ }^{1}$ Tasub ka märkida, et viimase 70 aasta jooksul on vähenenud mõnede pärismaiste liikide levik, ${ }^{2}$ mis mõjutab samuti nende kasutamist. Samas sageneb rahvameditsiinis üldiselt võõrliikide kasutamine (vt Kalle 2008).

Antud artiklis analüüsime ravimtaimede tundmist ligi 8700 seni digitaliseeritud ja HERBAsse lisatud viimase 130 aasta jooksul kogutud taimpärimusteksti põhjal ning anname ülevaate mõjukamatest ravimtaimetundmise mitmekesistajatest. Lisaks HERBA andmetele toetume Eesti Rahvaluule Arhii- 
vist hiljuti digitaliseeritud ainestikule (eeskätt Gustav Vilbaste kogu tekstid) ja autorite välitööde tulemustele (suvi 2009).

\section{Taimepärimuse tundmise võimalikud viisid}

Ravimtaimepärimuse võib tinglikult jagada kaheks suuremaks rühmaks:

1) Lokaalne pärimus levib otseste kontaktide ja pärimuse vahetu edasiandmisega abi osutajalt abivajajale. Peamiselt antakse edasi positiivseid ravitulemusi. Siiski võib olla taime edaspidine määramine raskendatud, sest üks kord kuuldud informatsioon või nähtud taim ei tarvitse olla meeles. Taime valiku määrab tihti selle üldine tähtsus kultuuris (vt Sõukand 2007a).

2) Globaalne taimravipärimus on tekkinud kaudsete mõjutajate (kirjandus, meedia jms) toel. Globaalne teave on väga mahukas, selle hulgast on raskem üles leida inimesele konkreetselt vajalikku teavet ja valikuvabadus ravimeetodite osas on suur. Samas tundub inimesele taime äratundmine kindlam, sest seda saab uuesti kirjanduse toel tuvastada (pikemalt äratundmise teemal vt Sõukand \& Kalle 2010). Globaalne pärimus tugineb väidetavalt keemilisel koostisel põhinevatele toimetele või ajaloolisele traditsioonile.

Kui lokaalset pärimust, eriti selle detaile, võib pidada Eestile iseloomulikuks ja tasapisi hääbuvaks nähtuseks, siis globaalne pärimus on rahvusvahelise iseloomuga ning sisaldab nii hääbuvaid (nt taimed, mis Eestis ei kasva) kui ka elujõulisemaid (nt lokaalset pärimust asendavaid) elemente.

\section{Lokaalne taimravipärimus}

Lokaalne taimravipärimus on tihedalt seotud kohalike ehk pärismaiste liikidega. Pärismaiseid liike on botaanikud loendanud Eestis koos pisiliikidega 1540 (A\&O 1987: 127). Need liigid ei ole Eestis kuigi ühtlaselt levinud. Visuaalselt annab Eesti taimestikust parema ülevaate Eesti taimede levikuatlas, milles on suurem osa (kokku 1353) looduslikult, naturaliseerunult, tulnukana või kultuurist püsivalt metsistununa leitud liikidest, alamliikidest või taksonitest (Kukk \& Kull 2005). Kaartidel on näha, kui ebaühtlaselt on liigid meil tegelikult levinud: sadadel kaartidel on vaid üksikud märked, mis tähendab, et tõenäoliselt neid taimi ei kasutatud. Ka on mitmed endisaegsed tavalised liigid muutunud tänaseks haruldaseks ja võetud kaitse alla. Kaitse alla võtmine ja liigi kadumine mõjutab lokaalset taimekasutust väga otseselt.

Veel sajand tagasi oli taimravipärimus (nagu ka kogu folkloor üldisemalt) valdavalt kogukonnakeskne (Sõukand 2007a). Taimepärimuse kandjateks olid 
enamasti naised. Naiste rolli selles osas suurendas ka praktiline vajadus: ravimtaimede korjamine ja kasutamine oli seotud rohkem laste kasvatamise ja vanurite põetamisega, sest mõlemad olid haiguste suhtes vastuvõtlikumad kui elujõus täiskasvanud. Esmased teadmised taimedest saadigi ühes leibkonnas elavatelt vanematelt ja vanavanematelt - lokaalne taimravipärimuse järjepidevus on suurem kui kaks inimpõlve. 19. sajandi lõpul tekkis maaga kauplemise tulemusena sisemigratsioon ja linnadesse koondumine (Pajur 2001: 176179). See soodustas eri paikade teadmiste segunemist: nt üldiselt Lõuna-Eestis levinud hariliku raudrohu Achillea millefolium nimetust verihein võib kohata Põhja-Eestis, Tallinnas, kus ajalooliselt oli levinud nimetus rauarohi (Vilbaste 1993: 124). Seda näitlikustab alljärgnev tekst, mis pärineb küll hilisemast ajast, jutustaja on kolinud Tallinna Võru linnast:

Suvel oli hea vere kinnipanemise rohi värske noor verihein. Selle tü̈̈as koos lehtedega lõigati peeneks puruks, puhas mahl sellest pigistati lapi sees purust välja teise lapi peale, nii et see ikka täitsa märg oli ja siis pandi haava peale, seoti ka kõvasti kinni. Kohe silmanähes mõjus, olen ise näinud! Aga ma pole kuulnud, et kuivast, talvisest veriheinast keedetud mahla üldse oleks tarvitatud vere vaigistuseks. (RKM II 383, 340 (25) < Tallinn l < Võru l - Eha Leek < Õie Jürgens, s 1918 (1984).)

Taimenimede ühtlustumine ja kirjakeelse botaanilise süstemaatika juurdumine Eestis tõi endaga kaasa mitte enam piirkonnale omase pärimuse. Samas võib maailmamastaabis võtta kogu Eesti ühtseks regiooniks ja kõiki siin kasutatavaid ühtseid pärismaiste taimede rahvuskeelseid nimesid võib tinglikult nimetada lokaalseteks. Lokaalset taimravipärimust võib eksimatult ära tunda juhul, kui on täidetud üks kahest kriteeriumist: taimel on olemas kas kohalik nimi või piirkonnale omane kasutus. Nende kombineerimisel on võimalik saada kolm rühma:

Esiteks: taime kohta on teada nii lokaalne nimetus kui ka piirkonnale omane kasutus. Selliseid teateid saab enamasti nendelt pärimusekandjatelt, kes kasutavad aktiivselt taimravi, püüdes sellega alal hoida ka endiseaegseid traditsioone.

Emanõgesed, nõianõgesed (Lamium alb.). Sigadelle lõuatõbe (kui sial muhud lõuapäras on) vastu sisse anda. Inimesele ehmatuse ja langetõbe vastu. (H II 34, 771 (12) < Kuusalu khk < Viru-Nigula khk - Hans Lohk (1892).)

See rühm on kõige arvukam, mis on ka ootuspärane, sest taimravi pärimuse kogumisel lähtutaksegi eeldusest, et inimene väljendab oma taimetundmist nimetuse ja kasutuse koosmärkimise kaudu. Selline teabe edasiandmine eel- 
dab, et intervjueerija või talletatud taimravipärimuse hilisem lugeja teab, kuidas nimetatud taim välja näeb ja tunneb valmistamise tehnoloogiat. Parema arusaamise huvides oleks kasulik anda edasi ka taime välimuse kirjeldus, kasvukoht ja leviku andmed. Kasutamiseks on vaja teada, kas kasutatakse juurt, ürti, õit või vilju, millal neid korjata, mis jällegi taandub taime tundmisele, sest on vaja teada võrsumise, õitsemise, viljumise ja närbumise aegu. Paraku ei kajastu nii põhjalik taimetundmine pärimuses just sageli.

Teiseks: taime kohta on teada lokaalne nimetus, nt küsitud on üksnes nimetust, arhiivitekstis puudub täpne näidustus. ${ }^{3}$ Taimenimetuse levikuala võib ulatuda talust, kihelkonnast (nt laste kõhurohuks kutsuti maamõõla Geum urbanum ainult Äksi kihelkonnas - EKS c, 62 (3b)), kuni mitme maakonnani (nt eespool toodud veriheina ja rauarohu näide). Järgmise teksti on kirja pannud Gustav Vilbaste ja Eesti Rahva Muuseumi suurkorrespondent Priidu Tammepuu mölder Juulius Sildvee kirja põhjal. Tekstis kirjeldatakse küll väga täpselt taime välimust ja kasvukohta (mille alusel on Gustav Vilbaste hiljem taime ka ära määranud), kuid kasuamise kohta ei osata öelda midagi täpsemalt kui arstirohuks tarvitamist.

Neid taimi, mis niitudel kasvavad, pruunika vartega ja õietupp on ka pruun, aga õis on kollakas, nagu mesilane seal varre otsas. Seda taime rahvas nimetab hobuse verekusemise rohi [Geum rivale] ${ }^{4}$. Juuri tarvitati ka teena arstirohuks ennemalt, aga ei tea, mis häda vastu. (Vilbaste, TN 11, $261<$ Tallinn 1 < Laiuse ja Torma khk, Sadala v - Priidu Tammepuu < Juulius Sildvee, s 1887 (1963).)

Võib väita, et selliseid teateid, kus taime täpset kasutust ei teata / ei öelda, on kirja pandud kogu taimepärimuse kogumise jooksul. Sellise vastuse saamise tõenäosust suurendab ka koguja poolt esitatud suunav küsimus korrespondendile.

Kolmandaks: taime kohta on teada tema kasutus, kuid arhiivitekstis puudub nimetus. ${ }^{5}$ Nagu eespool mainitud, tunnevad ka nende tekstide saatjaid kirjeldatud taimi, kuigi ei tea nende nimesid. Kirjelduse ja kasutuse kooskäsitlemise põhjal on pärimustekstis toodud taim tihti määratav liigi või perekonna täpsusega. Muidugi eeldab see määrajalt nii botaanilisi kui ka rahvameditsiinialaseid eelteadmisi. Üldiselt saab antud taimetundmise rühma jagada omakorda kolmeks alarühmaks, mida võiks tinglikult nimetada neid ühendavate fraaside järgi: ei mäleta nime, keegi rääkis (neid lauseid kohtab enamvähem võrdselt) ja sellisega raviti (mida esineb nimetust mitteteadvate korrespondentide tekstides kõige rohkem. Vaatleme järgnevalt, mis asjaolud põhjustavad selliste väljendite kasutamist ja kuidas taimesid siis määrata saab.

On märgata tendents, et nime ei mäletata vormel sageneb viimastel aastakümnetel kogutud tekstides kodukoha lähedal kasvavatest apofüütidest (inim- 
kaaslejatest) rääkimisel. Järgmises tekstis kirjeldatakse valge piimaga taime, mida kasutatakse soolatüüka raviks:

Soolatü̈̈ka vasta oli see hein, mis põllu pial kasvab ja valge piim tuleb tal välja. Vat nime ei mäleta. Meie kandis teda ei ole. Tolle piimaga tehti kokku ja siis kadus ära. (RKM II 413, 511/2 (5) < Rõngu khk, Härjanurme k < Puhja khk, Nasja k - Eda Kalmre < Elli Purm, 67 a (1988).)

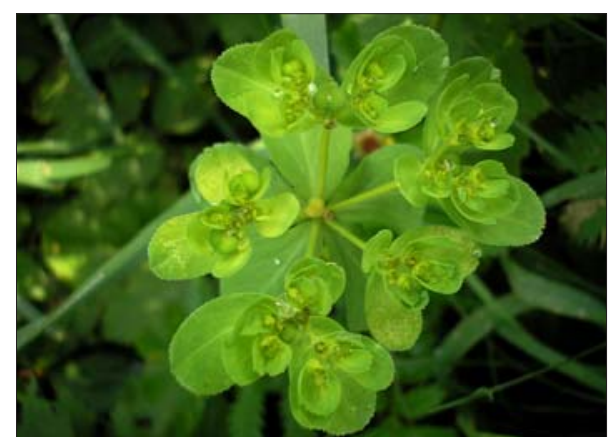

Foto 1. Hariliku piimalille nn piim on Eestis teada-tuntud nahahaiguste vastane vahend. Raivo Kalle foto.

Arvatavasti on tegu hariliku piimalillega Euphorbia helioscopia, mille iseloomulikud omadused ja kasvukoht vastavad tekstis kirjeldatule ning temaga on sagedasti ka soolatüükaid ravitud.

Kui teave on saadud võõralt inimeselt, võib aimata olukorda, kus taime nimetus ei jää informatsiooni edastamise käigus meelde või ei tundu isegi oluline. Järgnevas tekstis on algseks informatsiooni edastajaks võõras naine, kes, olles taime varem teiste ravimiseks kasutanud, soovitab seda korrespondendile. Siinjuures tundub isegi loomulik, et taime nimetust ei mainita, seda asendab taime kirjeldus ja kasutamisõpetus.

Üks päris võõras naine rääkis mulle, et tema saand metsas marjul olles ühe võõra naisega kokku, kes näidand temale ühte taime, mis parandab langetõbe. See taim on peenikeste lehtedega ja üks pisike kollane õis otsas. Selle taime teega oli see naine, kes mulle seda rääkis, kolm inimest terveks teinud. (RKM II 264, 344/5 (11) < Simuna khk, Käru k - Linda Palu < jutustaja ei soovi nime avaldada, s 1892 (1969).)

Arvatavasti on tegu hariliku kukeharjaga Sedum acre. Tuvastamist lihtsustab asjaolu, et sarnase välimusega taksonite seast kasutatakse langetõve raviks vaid ühte liiki. Allpool on lisatud määramist hõlbustanud tekst.

Keegi mees sai langetõvest terveks, tarvitades järjekindlalt kivistel kinkudel kasvava taime, kukeharja (Sedum acre L.) keedist, seda süües. (ERA II 193, 588 (54.20) < Põltsamaa khk, Pajusi v, Tamsi k - Jaan Lääts < A. Ehala (1938).)

Kõige enam esineb taimenimetusteta taimravitekstide hulgas vormelit sellisega raviti. Tihti esineb siingi taimekirjeldus ja konkreetne kasutus, mis aitab seostada tekstis kirjeldatud taime kindla liigi või perekonnaga. 
Järgmises tekstis kirjeldatakse samuti soolatüüka ravimiseks kasutatavat taime, kuid seekord teist liiki. Ilmselt on tegu hariliku vereurmarohuga Chelidonium majus, mille kirjeldus ja kasutus vastavad tekstis toodule.

Mina võtsin endal kõik soolatü̈̈kad ära. Selline lill, kasvab surnuaedades. Palamuse surnuaias on kiviaia peal. Ühe varre otsas, peal nagu ristikulehed. Kui katki murda, läheb valge piim kollaseks. Sellega määrisin. (RKM II 450, 566 (13) < Palamuse khk, Maaritsa k, Kooli t - Marju Leppik ja Astrid Tuisk < Linda Kolberg (s Tannenberg), s 1928 (1992).)

Põhjusi, miks taime nime mitteteadjate hulgas esineb rohkem vormeli sellisega raviti kasutajaid, võib olla päris mitu. Esiteks on põhjuseks kohaliku kogukonna puudumine, sest ei mäleta nime ja keegi rääkis vormelite kasutajatel on olnud otsene kontakt taimravi tundjaga ja ta on hiljem nime unustatud või pole seda lihtsalt talle edasi öeldud. Sellisega raviti vormeli kasutaja võis oma teadmised saada, nähes kedagi taimega ravimas, kuid ei ole nime küsinud või pole laskunud vestlusse. Ta võis hiljem seda taime ise kasutama hakata või ka mitte. Teine suurem põhjus võis olla eespool kirjeldatud taimenimede laiem ühtlustumine 20. sajandi 20. aastatel. Siis hakkasid laiemalt kasutusse juurduma enamasti kirjanduses ja koolihariduse kaudu süstemaatikast lähtuvad oiged taimenimed, mis võisid kattuda kohapeal kasutatavate nimetustega, kuid ei pruukinud. Kui küsitletav ei teadnud taime kirjakeelset õiget nime, võis ta segaduse vältimiseks jätta ka rahvapärase nimetuse ütlemata. Loetletud on osa põhjustest, miks nimetuse asemel kasutatakse deiktikut.

Võib väita, et kõigi ravimtaimetundjate hulgas on säilinud suuremal või vähemal määral tuvastatav lokaalne pärimus kas siis ravi või taime nimetuse osas, kuid mida hilisem tekst, seda rohkem on segunenud eri paikkondadest ja ka väljastpoolt kogukonda pärinev teave. Eriti jõuliselt kipub praegu domineerima globaalne ravimtaimepärimus.

\section{Globaalne taimravipärimus}

Globaalne taimravipärimus on tihedalt seotud kultuuris kasvatatavate taimedega, milledest, erinevalt pärismaistest liikidest, pole seni põhjaliku nimekirja koostatud, kuid neid arvatakse olevat üle 6000 (Kukk 2001). Uutel liikidel puudub rahvapärane taimenimetus, levivad enamasti botaanikute pandud nimetused. EMÜ botaanika doktorant Merle Ööpik on koostanud nimekirja võõrliikidest, mida on Eestis leitud juhuslikult või naturaliseerunult. Need on metsistunud või juhuslikult sisse toodud ja spontaanselt kasvama hakanud kultuurtaimed, nimestikus on kokku 787 liiki (Ööpik 2006). 
Mida ajas edasi, seda rohkem taandub lokaalne taimepärimus globaalse kaubanduse survel uute turule paisatavate loodustoodete (eukalüpti-, nulu-, teepuuõlid jne) ees. Endisaegsed kohapealsed samalaadse toimega taimesaadused jäetakse kõrvale, sest need ei tundu enam nii ahvatlevad. Lokaalsed teadmised on pigem loomulikud, peaaegu märkamatud, mingil perioodil ei peetud neid isegi mainimisväärseks, hiljem lisandunud kogukonnavälised teadmised eristuvad neist selgelt. Nimetagem need teadmised tinglikult globaalseteks ja mainigem, et vaatamata sellele, et neid võidakse edaspidi levitada juba kogukonna siseselt (kas muutmata või kohandatud kujul) ja taimi võidakse hakata pidama kohalikeks liikideks, erineb nende staatus lokaalsetest teadmistest ja nad on selgelt eristavad isegi siis, kui konkreetses pärimustekstis või intervjuus jäetakse mainimata, et teadmised pärinevad väljastpoolt kogukonda. Sissetoodud ravimtaimed sobituvad ajapikku kohalikku loodusse (nt harilik kalmus Acorus calamus) ja võtavad üle kohalike taimede kasvukohti, lõpuks hakatakse neid pidama kohalikuks liigiks. Teadmised võõrliigi raviomadustest pole enamasti saadud mitte huupi ise katsetamise meetodil, vaid väljastpoolt omandatud teabe alusel (vt Kalle 2008).

Globaalse ravimtaimepärimuse eristamiseks saab kasutada kolme markerit, mis võivad esineda kas koos või eraldi, kuid kõigis neis esinevad kas võõrtaimed, võõrtaimede nimetused või võõrapärane teave taime kasutamise kohta:

Esiteks: uus taim on võetud kasutusele. Võõrtaimel võib olla nii ametlik kui ka rahvapärane nimetus, kusjuures on tegu enamasti ainuomase nimetusega, mis ei ole üle kandunud kohalikelt liikidelt. Tegu on enamasti kultuurliikidega:

Aaland, aaslanger. Istutatud aedadesse. Loomadele luudehaiguse vastu keedetakse taime vett, jooksvavalu puhul inimesel mässitakse lehed ümber valutava liikme. (Vilbaste, TN 1, 670 (14) < Mihkli khk, Veltsa k Wold. Schmidt (1929).)

Eelnevas tekstis on korrespondent mõelnud aedades kasvatatavat ja kergesti naturaliseeruvat võõrliiki aedvaak (Inula helenium), nimetus alant ja selle teisendid pärinevad saksakeelsest nimest Alant (Vilbaste 1993: 371).

Teiseks: võõrtaime kasutus on kandunud kohalikule taimele, lisaks kasutusele on mõnikord kohalik taim omandanud ka võõrtaime nimetuse. Teisalt võis kasutus saada alguse kohaliku taime võorapärase nimetusega nimetamise tõttu, kusjuures võõrnimetus on hiljem ununenud. Võõrliik ise võib Eestis kas kasvada või mitte. Järgmises näites kirjeldatakse hariliku härjasilma Leucanthemum vulgare (vana nimetusega Chrysanthemum leucanthemum) kasutamist arnika nime kandva taimena. 


\section{Chrysanthemum leucanthemum}

Arnikas. Õied teeks pruukida, mis ilma suhkruta joodud peab saama. On hä̈̈ rohi seest äravenitamise vastu. (EKS c, $59<$ Viljandi khk - Mihkel Ostrov (1891).)

Selle ja järgmise teksti kõrvutamisel mõistame, kuidas harilikule härjasilmale (valgekeelõieline) omistatud võõrsil kasvava (kollasekeelõielise) arnika nimetus on andud kasutuse kõigile teistele karikakarde nime kandvatele liikidele. ${ }^{7}$

Katkestamine. Kui liigse raskuse tõstmise tõttu või töö tõttu jne. hakkab rinde alt valutama, siis öeldasse, et on enese ära kakestand ehk rinde alt ära venitand. Arstimiseks puhkus ja kuivatatud õitsvaist karikakardest keedetud jook, eriti hästi mõjuda õllega segamini joomine. (ERA II 42, 91 (22) < Kolga-Jaani khk, Soosaare v, Taganurga k - Otto Ibius < Kata Ibius, 58 a (1931).)

Mägiarnika (Arnica montana) oli ajastu moetaim Euroopas (19. sajandi keskpaigast), mille populaarsus levis Eestisse hiljem, 20. sajandi esimestel kümnenditel (Sõukand 2007b), ja tema nime eri kujud kandusid edasi mitmetele kohalikele liikidele. Üks neist taimedest oligi näitetekstides toodud harilik härjasilm Leucanthemum vulgare, mis iseseisvalt rahvameditsiinis kasutamist peaaegu ei leidnud, kuid võeti mõneks ajaks kasutusele nimetuse arnikas tõttu. Arnika-nimeliste taimedega raviti enamasti venindhaigust ja peamiselt keedeti neid õlles, mida propageeriti juba 1880. aastal (Pärnu Eesti-rahwa Kalender ehk Täht-raamat 1880 aasta pääle, pärast Jeesuse Kristuse sündimist). Viimases näitetekstis venitushaiguse ravist ongi toodud täpsustus, et seda tuleb juua koos õllega, mis tõestab veel kord, et see teadmine ei ole lokaalne, vaid sisse toodud. ${ }^{8}$

Kolmandaks: võortaime nimetus kandub kohalikule taimele. Konkreetne võõrtaim ei pruugigi Eestis kasvada, enamasti on tema nimetus üle kantud kohalikule taimele (või koguni mitmele taimele), mida laiemalt ei kasutata: Jalad valutasid, tegin sassapariladest (hanevitsadest) vanni. Suos kasvavad. (RKM II 349, 19 (7) < Iisaku khk, Jõuga k - Hilda Jõulmaa < Anette Vahtra, s 1897 (1981).)

Hanevitsa Chamaedaphne calyculata kutsuti sassaparillaks Virumaal ja Tartumaal (Vilbaste 1993). Sassaparilla nime aluseks on troopilises piirkonnas kasvavad smiilaks Smilax ssp. perekonna liigid, mida müüdi peamiselt apteekides. Eestikeelsete taimenimede andmebaasi (http://www.ut.ee/taimenimed/) järgi on nimega sassaparill märgitud vaid ühte liiki - Smilax ornata. Pärimuses kajastub nimi sassaparilla erinevate teisenditena (soosassaparilla(d), nõm- 


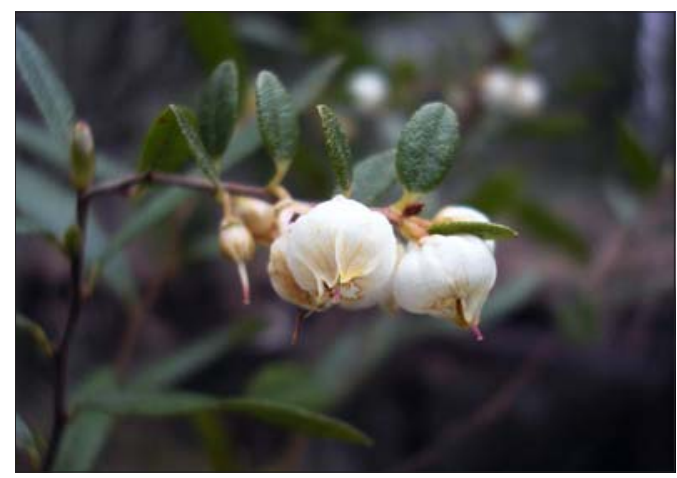

Foto 2. Hanevits on sassaparilla nime all kasutust leidnud jooksva vastu. Kui taandus sassaparilla nimi, lakati hanevitsa rahvameditsiinis üldse kasutamast. Raivo Kalle foto.

mesassaparilla(d)) kogu jälgitava pärimuse vältel. Et kõik võõras on eksootiline ja parem kui kodumaine, võeti ka see võõrapärane taimenimetus kasutusse. Gustav Vilbaste (1993: 153) kirjutab:

Sassaparid ja teised selletüvelised nimetused näivad kõik olevat moonutatud hispaaniakeelsest Sarsapareilha'st, mida saksakeelses rohuteaduslikus kirjanduses tarvitatakse Sarsaparille nime all. Sassaparilla nime on eriti levitanud rohueided, kes müüsid turgudel selle nime all Andromeda polifoliea, samuti ka Chamaedaphne calyculata (Cassandra calyculata) varsi ja Carex arenaria risoome mitmesuguste haiguste raviks.

Hanevits kasvab rabas, rabametsades ja soos ning teda on rahvameditsiinis kasutatud vaid sassaparilla nimetuse all. Arvatavasti omistati nn eksootilise imerohu sassaparilla omadused kaugel soos kasvavale taimele, millega oli igapäevaselt vähe kokkupuudet. Enamasti raviti sassaparilla nimetust kandvate taimedega jooksvat, liigesehaigusi ja teisi reumaatilisi valusid, mille üks tekkepõhjus on liigniiskus.

\section{Ravimtaimetundmise peamised globaliseerijad ${ }^{9}$}

Kui lokaalsed taimravialased teadmised pärinevad peaasjalikult vahetus läheduses asuvast kogukonnast, siis globaalsed teadmised ravimtaimede kasutamise kohta levivaid mitmeid teid pidi. Toome allpool ära kaks olulisemat globaalsete teadmiste levimise kanalit ajaloolise tähtsuse järjekorras.

\section{Apteegid ja rohupoed ${ }^{10}$}

Ajalooliselt suurt tähtsust omanud apteekide osa ravimtaimede tundmise suurendamises on arstiabi kättesaadavuse paranedes järjest vähenenud. Üheltpoolt vähendasid apteegid ja rohupoed taimede tundmist, sest asendasid ravimisel looduslike taimede kasutamise erinevate arstimite ja droogidega. Teiselt poolt aga suurendasid ravimtaimi kokku ostes ja kogumiseks selgitusi jagades taimede üldist tundmist. Apteekide mõju saab kaudselt hinnata, kui 
vaadata, kuidas on seal müüdavate droogide nimetused kandunud pärimusse, nagu eelmainitud sassaparilla juhtumi puhul. Apteekides müüdavad rohtude nimetused ei olnud väga täpselt reglementeeritud. Näiteks võis erinevatest apteekides roosisalvi nime all saada 1) ihtüoolsalvi (Unguentum Ichtyoli), 2) koldkreemi (Unguentum leniens) ja 3) silmasalvi (Unguentum Hydrargyri oxydati rubri) (Wallner 1929). Arstirohtude ja sealhulgas droogide nimede ühtlustamise aeg langeb samasse ajajärku uue botaanilise süstemaatika levikuga. 1914. aastal ilmus Heinrich Oskar Niggoli (1890-1918) neljakeelne (ladina, vene, eesti ja saksa) Eesti arstiteadusline sõnastik (Niggol 1914) ja 1920. aastal proviisor Rudolf August Vallneri (1879-1950) kokkuseatud Arstirohtude ladinaeestikeelne sõnastik (Wallner 1920). Samuti ilmus Vallnerilt tema aastatepikkuse kogumistöö tulemusena apteegidroogide nimetustega Eesti rahvarohtude sõnastik (Wallner 1929). Endisaegsete rohupoodnike mõju rahvameditsiinile üldiselt on raske hinnata, sest nende kaupade müügi üle kontroll puudus (vt Gustavson 1972: 181-190). Kuid tänapäevalgi saab looduslikke tervisetooteid osta mitte ainult apteekidest, vaid ka näiteks toidupoodidest. Järjest suurenev kontsentreeritud kujul müüdavate loodustoodete valik (kapslid, kreemid, õlid jne) apteekides ja poodides muudavad taimede kasutamist inimeste seas, sest kuigi tootetutvustuses kirjeldatakse ravimtaimede kasutamist, müüakse inimesele kapslit, millest taime kuju ei ole näha, mis võib omakorda tekitada segadusi tulevikupärimuses.

\section{Kibuvitsajuure droogi juhtumianalüüs}

Sellest, kui palju segadust võib tekitada üks droogi nimetus, annab põgusa ülevaate järgnev juhtumianalüüs. HERBAs on mitu teksti, milles räägitakse kibuvitsa juurte kasutamisest jooksva raviks: Kibuvitsa juured piirituse sisse panna, jooksva vasta. Puskariga koos määrida. (ERA II 37, 64 (66) < Jõhvi khk, Järve v, Kukruse k, Joorami t - Rudolf Põldmäe < Leenu Lasberg, 80 a. (1931).) Esmapilgul võib arvata, et tegemist on kibuvitsa (Rosa) juurtega, sest niimoodi on ju öeldud. Ent kui hakata lähemalt uurima, selgub, et kibuvitsa juuri ei ole kunagi ravimiseks tarvitatud. Rudolf Vallner annab selgitust, et droogina on kibuvitsa juurteks kutsutud hoopis villtakja Arctium tomentosum juuri (Wallner 1929: 44). Eestis kasutati takjajuuri jooksva vastu juba 19. sajandi esimeste pärimustekstide andmeil ja nad on leidnud kasutust veel 20. sajandi 60. aastate lõpus, seega on nad kasutuses olnud üle saja aasta, üle kahe inimpõlve. ${ }^{11}$ Takjajuure keedist kasutati ka näiteks Iirimaal muu hulgas reumaatiliste haiguste raviks (Allen \& Hatfield 2004).

Kibuvitsajuurte kasutamist kirjeldavad HERBA tekstid käsitlevad eranditult jooksvahaiguse ravi, ja need on pärit kindlast ajast ja ruumist: Virumaalt 
ja ainult 20. sajandi 30. aastatest 60ndateni ehk ajaliselt ühe inimpõlve. Järelikult on kibuvitsajuure nimetus pärinenud Virumaa apteekritelt, kes arvatavasti saatsid selle ka R. Vallnerile. Apteekrite kaudu levis see edasi droogi nimena. Kas nende tekstide autorid ka reaalselt kibuvitsa Rosa sp. juuri tarvitasid, ei ole enam võimalik kindlaks teha.

Vürtsi lisab üks tänapäevane pärimustekst, mis on ära trükitud Prillitoosi ravimtaimemängu raamatus ja käib kurdlehise kibuvitsa Rosa rugosa kasutamise kohta:

Juuri kogutakse sügisel. Juurtes on rohkesti parkaineid, mistõttu neid tarvitatakse sapi-ja neerukivide, põiepõletiku ja reumatismi raviks (Tarto \& Tammsaar 2008: 57).

Autorid intervjueerisid teksti saatjat, ja selgus, et ta ise ei ole neid juuri kasutanud, vaid oli neid kogunud koos emaga 20. sajandi kuuekümnendatel aastatel Tallinna turu tarvis müügiks (mis toimus poolsalaja). Edasisel usutlemisel selgus, et algselt tellis kibuvitsajuuri keegi mees Tallinnast, kes töötas meditsiinilaboris (Autorite kogu < Vastseliina khk, Lasva $\mathrm{k}<$ Valga $\mathrm{l}$ - Inge Hütt, s 1937 (2009)). Teaduspublikatsioone uurides selgub aga, et kurdlehise kibuvitsa juure aluselisel ekstraktil on ilmnenud tõepoolest põletikuvastane toime, vähemalt hiirtega tehtud katsetes (Jung jt 2005).

\section{Aimekirjandus- ja meedia}

Globaalseid teadmisi taimede kasutamisest tõid meile maakeelde tõlgitud aimeraamatud. Nende kaudu saadi teada uute taimede raviomadustest ja leiti kasutusel olnud taimedele uusi rakendusi või kasutamist keelavat informatsiooni. Vene impeeriumi esimeseks arsti- ja rohuteaduslikuks ajakirjaks peetakse Põltsamaal baltisakslasest arsti ja apteekri Peter Ernst Wilde (17321785) koostatud ja August Wilhelm Hupeli tõlgitud väljaannet Lühhike öppetus, mis sees monned head rohhud täeda antakse, mis ilmus aastatel 1766-1767 neljakümne ühe õhukese vihikuna, kokku 164 lk (Wilde 1766-1767). Samuti on oluline Wilde 1771. aastal ilmunud Arsti raamat nende juhhatamisseks kes tahtwad többed ärraarwada ning parrandada, mida loetakse eesti populaarteadusliku kirjanduse alguseks. Hiljem ilmunud raamatute nimekiri on võrdlemisi pikk, kuid seni on põhjalikult läbi uurimata neis sisalduv taimeravialane teave, ka oli nende levik üsna piiratud (Sõukand \& Raal 2004: 1746).

Võõrast teavet võeti vastu valikuliselt ja selle kinnistumine võttis aega. Nii oli näiteks vana kalendri mõju varasemale taimravipärimusele äärmiselt tagasihoidlik (Sõukand 2008), samas kujundas kalender märkimisväärselt eest- 
laste ajaloolist maailmavaadet (Paatsi \& Paatsi 2008: 11-12). Kalendrites tutvustatud taimravi võrdlemisi kasin kandumine rahvameditsiini on nähtavasti põhjendatav sellega, et kalendris oli taimravi marginaalse tähtsusega, sest kuni 1900. aastani mainiti seal ainult 18 taime üle kahe korra (Martsoo 2007: 24 põhjal). Segadust võisid tekitada ka taimenimed, mis polnud rahva seas peaaegu levinud ning valenimetused või ilmsed tõlkevead. ${ }^{12}$ Alates 20 . sajandi algusest hakkas ilmuma rohkesti ainult ravimtaimedest kirjutatud raamatuid (Sõukand \& Raal 2004: 1747-1748). Need muutsid rahvameditsiini juba märkimisväärselt (nt Kalle 2010).

21. sajandi alguses on ravimtaimeraamatud, nagu kalendrid minevikus, väga suure kasutatavusega. Eriti tuntakse huvi värviliste taimepiltidega raamatute vastu (Põltsamaa raamatupoe müüja suulised andmed Raivo Kallele 2009. aasta juunis). Usaldusväärsemateks peetakse teoseid autoritelt, kellel on teada kas arstikutse või akadeemilise ametikoha olemasolu. Akadeemilist hõngu on rõhutatud peaaegu kõigis ajaloo vältel ilmunud eestikeelsetes taimravi raamatutes (Stud Med Lääts, $d r$ Kneipp ${ }^{13}$ jne). Kindlasti on ravimtaimeraamatut hõlpsam müüa, kui lisatakse, et tegu on uuemate teaduslike uuringute tulemustega. ${ }^{14}$ Autorid kohtasid välitöid tehes tihti selliseid vastuseid nagu pean raamatust järgi vaatama, raamatus oli kirjas jne, mis näitab, et kirjasõna peetakse usaldusväärseks. Samas suhtuvad mõned inimesed ettevaatlikult teostesse, milles on liiga detailsed ja põhjalikud raviõpetused:

Lugesin ühte Vigala Sassi raviraamatut, kuid see tundus liiga keeruline, kõik need komponendid, mida omavahel segada ei tohtinud ja täpsed grammid, ei osanud neid üldse kasutada (Autorite kogu < Kambja khk, Sipe k < Setu khk - Niina Kivimaa 46 a. (2009)).

Taimravi teadmiste leviku seisukohalt tänapäeval üha rohkem populaarsust võitev meedia on samuti taimede tundmaõppimisele kaasa aidanud. Eriti erialasaated ja foorumid. Näiteks Vikerraadio Aili Paju (spordimeditsiini doktor, praegu vabakutseline kirjanik ja tervendaja) loodusminutid, Maalehe ravimtaimefoorum, kus vastab OÜ Elujõud juht ja ravimtaimekasvatuse spetsialist Aivar Siim (http://foorum.maaleht.ee/viewforum.php?id=23), Pereklubi foorumis vastab farmakognoosia dotsent Ain Raal (http://www.pereklubi.com/index.php? name=Ekspert\&ekspert=1) jne. Meedia mõju saab teada täpsemalt alles aastate möödudes. Kuid juba on märgata lauseid, kui räägitakse taimede tundmisest, lisades, et Aili Paju saates rääkis (autorite välitööd).

Aimekirjanduse ja meedia mõjul on lokaalne pärimus taandunud, ja võib väita, et raamatute mõjul hakati taimi kasutama nende keemiliste komponentide põhjal, samas endisaegsete taimekasutuste puhul lähtuti pigem taimest kui tervikust ja tema tähtsusest kultuuris. 


\section{Lõpetuseks}

Lokaalne taimravipärimus on tihedalt seotud kodumaiste liikidega ning seda antakse edasi enamasti suuliste õpetustena positiivsete näidete toel. Taime nimetus võib olla levinud nii ühe küla piires kui ka hõlmata suuremat regiooni. Lokaalse nimetuse ja kasutuse põhjal saab öelda, et tegu on piirkonnale omase teabega. Lokaalse vastand on globaalne taimravipärimus, mis on otseselt seotud võõrliikide laiema kasutamisega ja võõrliikide nimedega. Globaalse pärimuse puhul on ravimiseks kasutatava informatsiooni hulk suur ja kasutaja peab ise tegema selles valiku.

Tänapäeval on lokaalne ja globaalne pärimus segunenud rohkem kui varem, nagu on segunenud kodumaised ja võõrliigid looduslikes kooslustes. Taimravialaste raamatute väljaandmise intensiivistumine ja nende populaarsuse suurenemine ning meedia mõju on kahandanud rahvameditsiinis kasutatavate taimede mitmekesisust. Nagu eriliigiline looduslik heinamaa on andmas teed monokultuuriga põllule, nii aheneb ka rahvameditsiinis kasutatavate kohalike taimede valik, ning aina rohkem tuuakse koduaedadesse ja ravimtaimeaedadesse võõrliike ja tervisetoodetena sisse toodud meil mittekasvavaid liike.

Autorid tänavad Kalevi Kulli ja kahte anonüümset retsensenti artikli seisukohalt oluliste soovituste ja täienduste eest. Eesti ravimtaimepärimus on digitaliseeritud ning veebikeskkond ja andmebaas valminud Eesti Vabariigi Haridusja Teadusministeeriumi riiklikke programmide "Eesti keel ja rahvuslik mälu” ja "Eesti keel ja kultuurimälu” projektide, EAS-i projekti "Rahvapärimuse baasil uute ravimtaimede tuvastamise eeluuring” raames ning Eesti Kultuurkapitali ja Hasartmängumaksu Nõukogu toel.

\section{Kommentaarid}

1 Pärast Eesti Kirjanduse Seltsi Keeletoimekonna toimetuste nr 6a (Kodumaa taimed. I jagu Õistaimed) väljaandmist 1918. aastal (E.K.S. Keeletoimekond 1918) ja hilisemat kordustrükki.

2 Põhjalikumalt on kirjutanud sellest botaanikud Tiiu Kull ja Toomas Kukk artiklis “Globaalne ja lokaalne eesti taimestik" (Kukk \& Kull 2006: 10-17).

${ }^{3}$ HERBAS on need tekstid süstematiseeritud Haigus määratlemata kategooriasse

4 Siin ja edaspidi: kandilistes sulgudes on käsikirjale hiljem lisatud täpsustus.

5 HERBAs on need tekstid koondatud märksõna Taim nimetuseta alla.

${ }^{6}$ Võõrliikidest Eesti rahvameditsiinis kuni 1944. aastani on kirjutanud pikemalt Raivo Kalle (Kalle 2008). 
7 Karikakar [---] näivat kuuluvat mandril rahvakeeles kõikidele korvõielistele, millel on keskel õiepõhjal tihedalt kollasevärvilisi putkõisi ning ümberringi pärjana valgeid või kollaseid keelõisi (Vilbaste 1993: 160), kuid nimetus arnikas kattub neist vaid hariliku härjasilmaga ja selle tõttu ongi venitust ravitud karikakraks kutsutud liikidega.

${ }^{8}$ Pikemalt võib arnika nimetuse levimisest pärimuses vt Sõukand 2007b.

9 Eesti rahvameditsiini ravimtaimede ajaloolistest mõjutajatest vaata lähemalt "Ravimtaimed Eesti rahvameditsiinis" (Sõukand \& Raal 2004).

${ }^{10}$ Apteekidest ja rohupoodidest vaata Heino Gustavson Tallinna vanadest apteekidest kuni 1917. a. (Gustavson 1972).

${ }^{11}$ Andmed saadud HERBAst märksõnade takjas ja kobrulehed alt.

12 Näiteks 1857. aasta Eesti rahvakalendri koduapteegi lisas tutvustatakse rahva seas laiema levikuta taime rihu-peenlooka Descurainia sophia nime all ussi rohhi ja ilmse tõlkeveana harilikku soolikarohtu Tanacetum vulgare nimede raud rohhi ja were hain all, mis olid laiemalt hariliku raudrohu Achillea millefolium nimed jne (ERK 1856).

${ }^{13}$ Näiteks taimraviraamatust Tervistavad kodumaa taimed anti välja viis kordustrükki. Toome siinkohal tsitaadi viienda trüki eessõnast, mis võtab kokku ka eelnevates trükkides öeldu: "Alusena käesoleva kirjutamisel on tarvitatud paljusid uuemaid arsti- rohuteaduslisi tunnustatud teoseid ning muuseas järgmiste teadlaste uuringuid ja teoseid [---]" (Vinkler 1937: 2).

${ }^{14}$ Näiteks Tatjana Gorbunova väidab oma raamatu eessõnas: "ma toetusin seda raamatut kirjutades Peterburi Keemia- ja Farmaatsiaakadeemia farmakoloogia kateedri teadusuuringuile [---]" (Gorbunova 1999).

\section{Kirjandus}

Allen, E. David \& Hatfield, Gabrielle 2004. Medicinal Plants in Folk Tradition. An Ethnobotany of Britain \& Ireland. Portland Cambridge: Timber Press.

A\&O 1987 = Elusloodus. Eesti seene- taime- ja loomaliikide arv. Tüksammel, Helgi (toim). A ja O: taskuteatmik. Tallinn: Valgus.

E.K.S. Keeletoimekond 1918. Kodumaa taimed. 1. jagu, õistaimed. E.Ü.S. loodusteaduse osakond, E.K.S. keeletoimekond. Eesti Kirjanduse Seltsi Keeletoimekonna toimetused; nr 6a. Tartu: Eesti Kirjanduse Selts.

Gorbunova, Tatjana 1999. Seedeelundite haiguste ravimine taimede abil. Itra, Kaljo (tlk). Tallinn: Tallinna Raamatutrükikoda.

ERK 1856 = Eesti rahva Kalender se 1857 aasta peale pärrast J. Kristusse sündimist: Se Kalender on Öigeussu tunnistusse rahwa tarbeks sisseseädetud. Riia: Müller.

Gustavson, Heino 1972. Tallinna vanadest apteekidest kuni 1917. a. Tallinn: Valgus.

Jung, Hyun-Ju \& Nam, Jung-Hwan \& Choi, Jongwon \& Lee, Kyung-Tae \& Park, HeeJuhn 2005. 19 $\alpha$-hydroxyursane-type triterpenoids: Antinociceptive anti-inflammatory principles of the roots of rosa rugosa. Biological \& Pharmaceutical Bulletin 28 (1), lk 101-104. 
Kalle, Raivo 2008. Taimede võórliigid Eesti rahvameditsiinis kuni 1944. aastani. Magistritöö botaanika ja mükoloogia erialal. Tartu: Eesti Maaülikool. Käsikiri Eesti Maaülikooli raamatukogus.

Kalle, Raivo 2010 [ilmumas]. Toomingas Eesti rahvameditsiinis. Eesti Loodus.

Kriiska, Aivar (2004). Inimene ja loodus esiajal. Kukk, Toomas (toim). Pärandkooslused: õpik käsiraamat. Tartu: Pärandkoosluste Kaitse Ühing, lk 13-47.

Kukk, Toomas 2001. Taimed. Tulnukaid sama palju kui Kesk-Euroopas. Eek-Piirsoo, Liina (koost). Võõrliigid Eestis. Kes on tulnuktaimed ja -loomad ning mida nendega peale hakata. Tallinn: Keskkonnaministeerium, lk 15-20.

Kukk, Toomas \& Kull, Kalevi 1997. Puisniidud. Estonia Maritima: Lääne-Eesti Saarestiku Biosfääri Kaitseala väljaanne; nr. 2. Haapsalu: Lääne-Eesti Saarestiku Biosfääri Kaitseala Läänemaa Keskus.

Kukk, Toomas \& Kull, Tiiu 2005. Eesti taimede levikuatlas =Atlas of the Estonian Flora . Tartu: Eesti Maaülikool Põllumajandus- ja Keskkonnainstituut

Martsoo, Stella 2007. Ravimid 18. ja 19. sajandi eestikeelses kalendrikirjanduses. Mäetagused. Hüperajakiri 36, lk 7-34 (http://www.folklore.ee/tagused/nr36/martsoo.pdf - 11. juuni 2010).

Niggol, Heinrich Oskar 1914. Eesti arstiteadusline sõnastik. Tartu: Põhja-Balti Arstideselts.

Paatsi, Kristi \& Paatsi, Vello 2008. Kalender eestlase ajalooalase maailmapildi kujundajana 19. sajandi algusest 1905. aastani. Kiipus, Merike (koost). Oskar Kallase päev - XXII eesti raamatuteaduse konverents. 23. oktoobril 2008 Eesti Kirjandusmuuseumis. Ettekannete teesid. Tartu: Eesti Kirjandusmuuseumi Arhiivraamatukogu, lk 912

Pajur, Ago 2001. § 37. Majanduse areng 1870-1914. Eesti ajalugu 4. parand. tr. Mäesalu, Ain \& Lukas, Tõnis \& Laur, Mati \& Tannberg, Tõnu \& Pajur, Ago. Tallinn: Avita, lk 176-179.

Sõukand, Renata 2007a. Mis teeb taimest ravimtaime: taime ja haiguse vaheliste seoste liigitamise katse Jakob Hurda kogu taimravi tekstide põhjal. Acta Semiotica Estica IV. Tartu: Eesti Semiootika Selts, lk 160-174.

Sõukand, Renata 2007b. Kuidas võõras muutub omaks: kaks taime eesti rahvameditsiinis. Mäetagused. Hüperajakiri 36, lk 79-104 (http://www.folklore.ee/tagused/nr36/ soukand.pdf - 10. juuni 2010).

Sõukand, Renata 2008. Ravimtaimed vanades kalendrites ja pärimuses. Kiipus, Merike (koost). Oskar Kallase päev - XXII eesti raamatuteaduse konverents. 23. oktoobril Eesti Kirjandusmuuseumis. Ettekannete teesid. Tartu: Eesti Kirjandusmuuseumi Arhiivraamatukogu, lk 14-15.

Sõukand, Renata \& Kalle, Raivo (koost) 2008. Historistlik Eesti Rahvameditsiini Botaaniline Andmebaas (HERBA) (http://herba.folklore.ee - 12. juuni 2010).

Sõukand, Renata \& Kalle, Raivo 2010. Plant as object within herbal landscape: different kinds of perception. Biosemiotics 3 (3), DOI 10.1007/s12304-010-9078-9. 
Sõukand, Renata \& Raal, Ain 2004. Ravimtaimed Eesti rahvameditsiinis. Ajalooline taust, etnofarmakoloogiliste andmete kogumine ja analüüs. Akadeemia 16: 8, lk 17341762 .

Tarto, Hille \& Tammsaar, Riina (koost) 2008. Prillitoosi ravimtaimemäng. ETV saatesarja "Prillitoos" ravimtaimemängu saadetud kirjadest ja kaastöödest. Tallinn: Maalehe Raamat.

Vilbaste, Gustav 1993. Eesti taimenimetused [Nomina vernacula plantarum Estoniae]. Emakeele Seltsi Toimetised nr 20 (67). Tallinn: ETA Emakeele Selts.

Vinkler, Reinhold 1937. Tervistavad kodumaa taimed. Mõjuvaid taimrohte haiguste vastu. Uusima arsti ja rohuteaduse alusel. 5. täiend. ja ümbertööt. tr. Tartu: A. Kadaksoo.

Wallner, Rudolf 1920. Arstirohtude ladina-eestikeelne sõnastik. Tartu: Eesti Kirjanduse Selts.

Wallner, Rudolf 1929. Eesti rahvarohtude sõnastik. Käsiraamat apteekritele ja arstidele / kogunud hulga kaastööliste abil ja kokku seadnud Rudolf Wallner. Tallinn: R. Vallner.

Wilde, Peter Ernst 1766-1767. Lühhike öppetus mis sees monned head rohhud täeda antakse, ni hästi innimeste kui ka weiste haigusse ning wiggaduste wasto, et se kellel tarwis on, woib moista, kuida temma peab nou otsima ning mis tulleb tähhele panna igga haigusse jures. Hupel, August Wilhelm (tlk). Pöltsamaa: Wilde, Peter Ernst.

Ööpik, Merle 2006. Võõrliikide andmebaasi käsikirjaline versioon 11.04.06. seisuga.

\title{
Summary
}

\section{An Insight in the Diversity of Estonians' Knowledge regarding Medicinal Plants}

\author{
Raivo Kalle \& Renata Sõukand
}

Key words: Estonian herbal folklore, ethnobotany, local and global, medicinal plants, naming of the plants, transmission of knowledge

The article probes the knowledge of Estonians in terms of medicinal plants, proceeding from the origin of the relevant knowledge. We have differentiated local and global knowledge. The concept of locality is closely related to indigenous plants and the knowledge thereof within the community. It is intrinsic of the local knowledge to combine two reciprocal criteria: first, the plant name is characteristic of a particular region (village, former parish, etc.), or, if there is no plant name, there is a recognisable description of the plant; secondly, unique and characteristic use of plants in a particular region. Global herbal folklore is associated with non-native and cultivated species, and can be recognised from among the relevant data according to the specific naming and intrinsic use of non-native plants, or by transferring the name and use of the alien plant to the local species, etc. 
In most cases, the introduced species do not have a folkloric name and are known only by way of the naming given by botanists. Pharmacies and chemist's are the first major and recognisable institutions affecting herbal folklore, as the names of the sold drugs coincided with the names of species. The more thorough analysis focuses on how widespread in oral tradition is the name of the drug made of the roots of the wild rose. Likewise, diverse herbal knowledge has also been influenced by popular science books in Estonian, published for nearly 340 years, and is currently affected by the media and the relevant influential figures presented therein. A number of species, which used to be common, have become rare during recent decades and a similar tendency can also be noted in herbal folklore. 